\title{
Internet and Islamic Learning Practices in Indonesia: Social Media, Religious Populism, and Religious Authority
}

\author{
Dindin Solahudin 1,*(i) and Moch Fakhruroji ${ }^{2, *(1)}$ \\ 1 Department of Islamic Community Development, Universitas Islam Negeri Sunan Gunung Djati, \\ Bandung 40614, Indonesia \\ 2 Department of Communication Studies, Universitas Islam Negeri Sunan Gunung Djati, \\ Bandung 40614, Indonesia \\ * Correspondence: dindin.solahudin@uinsgd.ac.id (D.S.); moch.fakhruroji@uinsgd.ac.id (M.F.)
}

Received: 6 November 2019; Accepted: 24 December 2019; Published: 31 December 2019

\begin{abstract}
Like in many other developing countries, Indonesia's population has been amongst the most enthusiastic 'uptakers' of the internet, especially of social media. Most Indonesians utilize the internet as an information source, including religious ones. Various groups and communities of Islamic studies have appeared on social media along with religious leaders who are also active on social media. Based on the various characteristics that have emerged, Islamic learning practices scattered across various social media platforms have increasingly illustrated the symptoms of religious populism. This is marked by the various socio-religious movements that have emerged from these practices. By using a digital religion perspective in order to observe Islamic learning practices on several social media platforms, this paper argues that social media has become a productive space for the development of religious populism in Indonesia. At first glance, religious populism on social media seems to challenge authoritative figures or religious institutions, but it can also be seen as a way for Islamic agents to convey Islamic teachings in a media-friendly culture.
\end{abstract}

Keywords: digital religion; Islamic learning; religious populism; social media; digital culture

\section{Introduction}

In early August 2018, social media users in Indonesia were shocked by a statement from a Bandung-based millennial and pop-stylish preacher, Evie Effendi. In a pengajian (Islamic lecture) circulated through his Youtube channel, Effendi mentioned that every human was misguided, including the Prophet Muhammad. This statement was revealed when he interpreted chapter 93 of the Quran. Realizing his mistake, Effendi immediately apologized, but some had already reported Effendi for insulting the Muslim religion. Many religious leaders considered Effendi's statement to not represent the views of an ustadz, who should have adequate religious knowledge, as Effendi cannot interpret the Quran verses 'correctly'. Blasphemies and warnings from the Indonesian Ulama Council (Majelis Ulama Indonesia, MUI) of Bandung and several leaders of Islamic mass organizations indicated that Effendi was considered to have no authority, so his teachings could lead to public religious misunderstandings.

In addition to the risks of misunderstandings, religious learning on the internet risks the emergence of radical understandings. This was stated by the Minister of Religious Affairs of the Republic of Indonesia, Lukman Hakim Saifuddin. Lukman stated that millennials should not learn Islam from the internet but preferably from authoritative figures or institutions. The rapid growth of radical religious sites since 2003 has become a concern for religious life in Indonesia (Dream.co.id n.d.). This concern seems quite reasonable since internet usage is increasingly widespread and has become a part of everyday life. Especially for millennials, as mentioned by Lukman, the internet has the potential to 
become a primary source for accessing religious knowledge and eliminating traditional authorities. Again, discussions about the relationship between the internet and religion have great significance.

When the relationship between the internet and religious studies first came to the attention of academics, online and offline contexts were still considered to be separate entities. However, due to the interactive nature of the internet and its ability to create a so-called cyberspace, the direction of research on religious and internet relations has become more complicated. Some religions have begun to show concern over the presence of the internet, which is seen to threaten the existence of conventional religious practices that are generally offline. This was illustrated in a study conducted by orthodox Jewish communities, who revealed the ambiguity of the internet's role in religion (Golan and Stadler 2016). Another study outlined the impact of online worship practices in seven popular churches in Nigeria. This study discovered that online worship has led to the emergence of an 'Internet church' and has had an impact on the dualism of church membership status (Chiluwa 2012).

These studies show an increasingly complicated relationship between the internet and religion, where online religious practices have the potential to become a threat to conventional religious practices that are usually offline. A useful concept to understand this concern is the concept of religious populism. Today, religious populism is generally represented by the efforts of religious orthodoxy to strengthen its position. In an Indonesian Islamic context, religious orthodoxy is generally represented by the MUI or main Islamic organizations, such as Nahdhatul Ulama (NU) or Muhammadiyah. These mainstream authorities are now facing challenges related to the emergence of populist preachers who have been "promoted" by the internet, especially social media, and are often not connected to the MUI or Islamic organizations.

The presence of preachers on the internet and social media seems to create its own influence through the formation of communities that then carry this form of Islamic activism into a wider public space (Lengauer 2018). This implies that some Islamic activism does not originate from mainstream Islamic organizations. In general, social media has encouraged the birth of religious populism through the rise of varied and popular patterns of Islamic learning. In fact, some of these patterns have led to the emergence of socio-religious movements that challenge religious organizations' elite in Indonesia.

Therefore, digital religion studies is useful for understanding the phenomenon of religious populism in the digital era. Digital religion studies entails field research in line with the development of internet studies. Digital religion studies are usually used to understand the impact of digital media on religion in digital culture in a broader context. The relevance of this approach within the context of religious populism can be seen in three general research areas: ideas of religious identity, authority, and community, which generally describe how religion is experienced and understood in a variety of digitally mediated contexts (Campbell and Evolvi 2019). In this respect, digital religion is understood as the exploration of the connection and interrelation between online and offline religious contexts and how these contexts become bridged, blended, and blurred over time (Campbell 2013). Therefore, this article aims to describe Islamic learning practices on the internet in an Indonesian context as a form of religious populism by using a digital religion perspective, where the unique characteristics of digital technology and culture coincide with religious expressions and practices in the context of new media.

\section{Digital Religion, Islamic Learning, and Religious Populism}

As a growing field of research, the direction of the internet and religious research shows dynamic development. Campbell even proposed religion as a new microcosm in internet studies (Campbell 2012). In general, digital religion has garnered attention since $\mathrm{O}^{\prime}$ Leary's study of how the internet functions as a sacred space (O'Leary 1996). In the early stages of its development, digital religion studies focused on how religion introduced online practices by considering the advantages and disadvantages of the internet (Brasher 2001), before exploring how religion is adapted in online practices (Bunt 2003, 2010), as well as the emerging phenomenon of cyber-religion and digital religion (Campbell 2005a, 2005b, 2007; Cloete 2016; Helland 2005). 
Some researchers have used a number of theoretical approaches for digital religion studies, including mediation (Hoover 2006; Martin-Barbero 1993) and mediatization (Giorgi 2019; Hjarvard 2011a, 2011b; Loveheim 2008). In line with the development of the direction and focus of this research, the internet is not only an arena where religion appears as content but has also given rise to religious patterns in cyberspace. Religious groups promote and practice their beliefs, making cyberspace a new arena that is more open to interpretation, which represents the phenomenon of so-called liquid religion (Possamai and Turner 2014).

Theoretically, the presence of religious discourses and practices in cyberspace is explained through the concept of cyber-religion or digital religion, which is practically differentiated into more specific "online religion" and "religion online" (Brasher 2001; Dawson and Cowan 2004; Helland 2004) or "religion on cyberspace" and "religion in cyberspace" (Karaflogka 2002). These two terms describe how religion is performed online and conceived of offline in this digital age and was framed by Campbell as "networked religion". This concept highlights five core characteristics: networked communities, storied identities, shifting authorities, convergent practices, along with multi-site reality, which also represents a core research focus for scholars of digital religion. Not surprisingly, today's digital religion studies explore more than just the manifestations of religion on the Internet; they also include the study of diverse technologies, such as cell-phone use, religious intersections within digital gaming, and even religious practices facilitated by mobile apps (Campbell et al. 2014).

Specifically, this article is focused on Islamic learning practices on the Internet. Islamic learning is defined as the practice of accessing Islamic knowledge, which is theoretically framed as $d a^{\prime} w a$ (Islamic proselytizing). In other words, the practice of Islamic learning is carried out in a more informal context than the concept of Islamic education understood in a formal framework. Traditionally, Islamic learning practice is usually performed through face-to-face interactions in pengajian (Islamic lectures) and takes place in mosques, madrasas, or other specific places (Millie 2017) and is contextualized as religious engagement.

This is why authority is significant in Islamic learning practices, since religious discourses are always related to the concept of authority. According to Lawrence (2002), authority in Islam is categorized into the following: (1) scriptural, a type of authority that refers to the Quran as the main religious text; (2) charismatic, a type of authority that refers to the character of the Prophet Muhammad as a role model generally known as a hadith or sunnah; and (3) juridical, a type of authority that refers to law as a foundation for religious ritual practices. As such, religious authority is not always institutional but can also be individual (Solahudin 2008).

These types of authority often appear simultaneously within internet content, both in websites and social media. Therefore, Islamic learning practices through religious counseling services that involve speaking with ulama online represent a potential struggle between traditional authorities and new sources of authority. The presence of online authority is usually characterized by the emergence of tension between new authoritative figures in an online context and religious figures/institutions in a traditional-offline context. This concern has been present since the 1990s, when changes began to occur in religious practices, as the internet became more popular in people's spiritual lives (Zaleski 1997).

Since virtual space on the internet symbolizes individual freedom, inclusiveness, egalitarianism, and multifaceted interactions among individuals and groups (Castells 2009), a person or particular group is able to build structure and authority. The emergence of figures on social media and unofficial websites for certain religious figures/institutions illustrates the phenomenon that the internet threatens traditional and "legitimate" sources of religious knowledge. Cyberspace has allowed religion to become more fluid so that religious authorities are relatively more spread out, thereby leading to populism.

Practically, populism is often understood as a type of organization characterized by charismatic leaders. Thus, populism is not only understood as an ideology but also as a political strategy employed by the populist leadership or groups who base their power on direct, unmediated, non-institutionalized support from large numbers of mostly unorganized followers (Weyland 2001). Unsurprisingly, the study of populism is commonly related to the political context and is even considered a key feature of the 
contemporary political landscape (Moffitt and Tormey 2014). Populism is generally understood as something that involves some kind of exaltation of and appeals to 'the people'; all populist groups are in one sense or another anti-elitist (della Porta 2014), thus leading to political subjectivity.

Some scholars have related the concept of populism to democracy, since both concepts contain a central reference to sovereign rule. Thus, both of them raise problems about their mutual relationship (Abts and Rummens 2007). Although considered dangerous for constitutional democracy (Urbinati 1998), some argue that this relationship remains ambiguous. Arditi (2003) argues that although populism is dangerous to democracy, it also functions as a "redemptive force" to ensure the implementation of the broken promises of the democratic system. In addition, populism can also be understood as a strategy where new social groups can enter the democratic process (Ernesto Laclau 2005). Populism is even considered to be one of the inherent elements of constitutional democracy. Therefore, populism is only considered a threat when a dominant populist element marginalizes others in a paradoxical combination (Arditi 2003).

Specifically, Moffitt and Tormey (2014) focused on contemporary populism as a political style in order to acknowledge the changing shape of the political landscape under conditions of reflexive modernity. Utilizing this framework, religious populism can be interpreted as a phenomenon where religious authorities face challenges from the creation of new religious figures or movements as a result of globalization (Moffitt and Tormey 2014). At some point, religious populism began to challenge religious orthodoxy, since populism is not only supported by the increasing penetration of modern processes like capitalism, scientific innovation, and bureaucratic organization but also the impact of post-modern and digital technologies, along with the transnational flows of images, symbols, and ideologies.

Religious populism has been studied with different focuses, both as a form of public discourse and as a series of organizational political movements. For instance, the religious populism of church-based movements became the forerunner of the broader populist movement (Mussio 1996). In the context of the Arab world, populism is considered a problem when dealing with Islamic values for implementing 'civil' society (Ibrahim 1998).

For religious populism on the internet in an Indonesian context, emerging studies include research on clicktivism in "Aksi Bela Islam" (Islam Defending Action), which has become a mass politico-religious movement (Ahyar and Alfitri 2019). In addition, other studies have described online and offline socialities and the uses of digital technology in the development of Muslim subjectivity among leaders and members of the komunitas (community) (Lengauer 2018). Social media has also become an important forum for expressing Muslim piety in contemporary Indonesia (Husein and Slama 2018).

Regarding concerns over the internet as a threat to traditional religious authorities, Campbell noted that this concern is centered more on particular roles and hierarchies, especially legitimacy, since the internet provides a space for renegotiating authority, as demonstrated by internet users who spread religious messages. Therefore, to understand the phenomenon of religious populism on the internet, one must also consider how authority is formed, maintained, and communicated in networking communities and the importance of reconsidering previous debates about the nature of authority and those who have legitimacy in certain religious groups in the internet era (Campbell 2007).

The relationship between religion and the internet is essentially reciprocal (Campbell 2005a). This reciprocal relationship was built on the thought that every religion studied online is fundamentally interconnected with its offline contexts. In other words, religious practice and religious discourse in online and offline contexts are always related simultaneously since online practices are formed by a user's state-of-being in an offline context (cited in Helland 2004). Under this assumption, the separation of online and offline contexts is no longer relevant since the online-offline distinction is increasingly blurred (Campbell and Loveheim 2011).

Campbell and Loveheim suggested that online religious practices are understood in several frameworks: how religious authority is negotiated by actors and structures online and offline, the integration of online and offline religious spaces, and the negotiation between online cultural 
values/norms and offline religious discourse. These three elements illustrate the importance of analyzing the interactions between and interdependences of religions in online and offline settings, to interpret the birth of online religious practices as a form of religious populism in the context of contemporary media-saturated society.

This suggestion implies the importance of religious actors and institutions in negotiating their positions and roles in online and offline contexts to create constructive relations between religious practices both online and offline. Thus, religious leaders and institutions are still very relevant (albeit transformed), rather than simply being weakened (Cloete 2016). In other words, religious populism on the internet and social media is a necessity and cannot be considered only as a challenge to authority. Populism also provides an opportunity to expand authority in the context of digital and contemporary society due to the fact that the relationship between religion and the internet is essentially reciprocal. However, this must be proven by the ability of religious actors and institutions in an offline context to negotiate with online contexts.

\section{Method}

This research uses a case study by observing texts on social media and other internet resources related to the context of Islamic learning practices on the internet and social media. In addition, the data also consist of descriptions obtained through online and offline interviews with purposively determined informants, comprising providers of Islamic information services through internet platforms, websites, social media, and smartphone applications. Thus, this research is focused on how Islamic information is produced and circulated on the internet.

This study was conducted throughout 2018. The platforms chosen as the focus of this study were the Cyberdakwah.com website, the Tafaqquh Video Channel, the Instagram account of @gustaqi, and the Aa Gym smartphone-based app. Cyberdakwah.com was chosen because of its constant activity in providing Islamic Q\&A services, while the Tafaqquh Video Channel was chosen due to its popularity as a channel containing Islamic lectures. The Instagram account of @gustaqi, on the other hand, is considered representative, as it is managed directly by religious leaders. Meanwhile, the Aa Gym app was chosen since it is managed by K.H. Abdullah Gymnastiar, who was one of the first figures to use cutting-edge technology for Islamic lectures in Indonesia.

The data will be described in detail to illustrate the practices of Islamic learning on the Internet in relation with religious populism and religious authority in Indonesia and analyzed using a digital religion studies perspective, which identifies how religious actors and structures are negotiated in an online and offline context, how to integrate online and offline spaces, and how these online and offline contexts are negotiated by religious figures.

\section{Internet-Based Islamic Learning as Religious Populism: Indonesia's Cases}

The internet in Indonesia is a paradox. In certain regions, the number of internet users is very high, while in other regions there is still a digital divide. Based on the 2015 Puskakom UI report, the majority of internet users in Indonesia are concentrated in the western region, especially Java, with penetration rates up to 36.9 percent of the population, with around 83 percent living in urban areas (Purbo 2017). The enthusiasm of Indonesians towards the internet is extraordinary. Based on the 2015 e-Marketer report, Indonesia ranked third for total internet usage, with the highest number of Facebook users in the world (id. techinasia.com n.d.). For those who live in urban areas, digital technology is increasingly becoming a part of life, work, culture, and identity (Jurriëns and Tapsell 2017). The Internet has also become a reference for knowledge, including religious knowledge.

The presence of Islamic knowledge on the internet has responded to the emergence of new kinds of religious engagements (Fakhruroji 2018), including the emergence of online religious counseling (Abdel-Fadil 2015). In the context of Southeast Asia, using the internet to spread Islamic knowledge is characterized by the emergence of cyber-da'wa as a further development of the practice of da'wa, which has previously used other media, such as the radio, audio-cassettes, and television (Weng 2015). 
Studies related to the internet in the context of Indonesian Muslims generally provide an overview of the enthusiasm towards new technologies, including how people use these technologies for religious purposes.

Barendregt described the study of the internet and digital culture in Indonesian Muslims' lives as Islamizing modernity versus modernizing Islam (Barendregt 2009). More specifically, the internet has offered a new public space for women to reflect on both religious and female interests (Slama 2010) and has also played a role in building relationships between preachers and followers by establishing religious authority (Slama 2017). In addition, social media is also used for da'wa to share Islamic knowledge among Muslims teenagers (Nisa 2018).

Thus, these internet platforms have become a forum for the circulation of Islamic knowledge, which also reflects religious populism as discourse that is free from the "bureaucracy" of religious authorities. Utilizing cutting-edge technologies for religious purposes has become a digital lifestyle for Indonesian Muslims, who are increasingly populist. To illustrate the growing phenomenon of Islamic learning on the Internet in Indonesia, this article uses examples from various internet platforms, such as websites, social media, and smartphone-based apps, which are the most popular internet platforms in Indonesia.

\subsection{Islamic Website}

As the most basic feature and platform of the internet, websites are technically defined as a number of virtual pages linked to each other and accessed using a browser. Technically, based on this definition, Islamic websites can be understood as a series of web pages containing Islamic contents. There are many Islamic websites in Indonesia, one of which is Cyberdakwah.com (http://www.cyberdakwah.com). Although this website is not an official website for a religious organization, it is understood to seriously convey Islamic messages and knowledge. Its Islamic contents are updated daily (both news and other information related to Islam); one key feature provided by this website is a question-and-answer for Islamic issues.

This indicates how actors and religious institutions digitalize Islamic learning by providing religious information that was originally performed via face-to-face interactions in the traditional-offline context on a daily basis. Negotiations performed by religious actors and institutions are marked by a collaboration between KH Ahmad Muzammil and his team in Pesantren (Islamic Boarding School) in Situbondo, to serve the questions and answers featured on this website. As Pesantren is one of the religious institutions considered to be authoritative on religious matters in Indonesia, this site shows that actors and institutions can maintain and expand religious authority in an online context. In order to access this feature, users can use two methods: by filling out the online form provided or by email. Questions are generally categorized into two kind of problems. First, issues of worship practices related to figh (Islamic jurisprudence), specifically those related to certain rituals or legal status and other related problems; Secondly, issues related to muamalah or how to implement Islam through daily social values. These features illustrate the interactions between religious figures and followers, as they are performed in traditional Islamic learning practice.

The following is one of the topics featured in the Q\&A on Cyberdakwah.com:

Peace be upon you, I am Andri Hermawan (24). I would like to get an explanation related to the law of wearing the burqa for women. There is an explanation by Imam Shafi'i that women must cover their entire body including the face when they meet men who are not mahram. Meanwhile, there is other information that explains that the veil does not originate from Islamic teachings. I ask for an explanation regarding this matter. Thank you. (Andri Hermawan/Magelang).

Then the response to that question is as follows,

Peace be upon you. Dear Questioner, may Allah bless you always. The issue of wearing the niqab for women is actually still debatable. Due to space and time limitations, we will not explain in detail these differences. However, the use of the niqab in the Indonesian context will experience many 
obstacles because this problem is still disputed by jurists, and Shafi'i schools are not the only figh schools in Indonesia, but also Hanafi, Maliki, and Hanbali. Thus, what is needed is wisdom in seeing the differences in views about this and that these views do not need to be contested but must be read according to their respective contexts. That is the short answer we can provide. Hopefully it can be understood properly. We are always open to receiving suggestions and criticisms from readers.

Cyberdakwah.com is a light example of the negotiation between religion and the internet. This website shows its authority by relating its existence to a traditional-offline context through collaboration with Pesantren to serve questions. In the context of Indonesia, Pesantren are recognized as Islamic educational institutions and are considered to have authoritative religious knowledge. Thus, Cyberdakwah.com represents a reciprocal and constructive relationship to deal with the phenomenon of religious populism, allowing religious figures to maintain their authority in the context of a digital society.

\subsection{Islamic Social Media}

Social media is generically defined as internet platforms focus on user-generated content. Technically, social media develop from social networking sites that allow users to connect with each another. The ability of social media to connect users with news feeds and share photos and videos that are equally enriched by users has made this the most popular and favorable type of internet platform, including in Indonesia. As reported by WeAreSocial on January 2016 (WeAreSocial n.d.), active Indonesian social media users reached 79 million, or around 30 percent of the total population. Of the total number of active users, 66 million users, or around 25 percent of the total population, accessed social media via mobile devices. There are several popular social media platforms in Indonesia, and this article observes two dominant platforms used as sources of Islamic knowledge: Youtube and Instagram.

\subsubsection{Tafaqquh Video}

Among the many Youtube channels that consistently provide Islamic knowledge is the Tafaqquh Video Channel (https://www.youtube.com/user/tafaqquhvideo). This channel is managed by the Tafaqquh Study Club, an Islamic study group based in Pekanbaru, Riau, Indonesia. Since March 2012, this channel has become a medium for disseminating Islamic lectures. Videos on this channel are dominated by Islamic lectures delivered by Ustadz Abdul Somad (UAS), one of the most popular religious preachers in Indonesia in the last six years. As of July 2019, the total views on this channel reached $204,668,852$, and it had $1,603,872$ subscribers.

Many people who access this channel then redistribute the videos through their personal social media; some videos also appear on other Youtube channels. The channel administrator does not see this as a problem; instead, they are grateful for religious messages can be disseminated more widely. However, the administrator has several conditions for those who intend to re-share the videos, including the following: (1) do not change titles into anything provocative; (2) do not cut and edit the video, as this could lead to a misunderstanding; (3) do not combine the video with other videos toto prevent any confusion; (4) do not monetize, advertise, or use the video as a means to gain commercial benefits; and (5) put the Tafaqquh Channel as the source.

These five conditions are a disclaimer used to protect the channel's authority as an institution that propagates Islam through the internet. In addition, their consistency in displaying religious lectures delivered by UAS with his religious authority has strengthened this channel's position as a reference for internet users. Videos on this channel not only contain thematic lectures (which are usually part of the celebration of Islamic holidays) but also feature a problem-based learning lecture style. Through this channel, Indonesian Muslims obtain religious information based on their needs, and this channel has become part of their daily lives, thus illustrating the reciprocity of online and offline contexts. 


\subsubsection{Instagram @gustaqi}

This article also analyzes the Instagram accounts of @gustaqi, which presents Islamic learning practice on social media and is managed by Ustadz Yudin Taqiyudin, a preacher based in Jakarta and the surrounding area. Taqiyudin expressed several reasons behind his use of the name @gustaqi for his Instagram account. Traditionally, in an Indonesian context, the term "gus" a quite popular term related to a Pesantren neighborhood, especially in the East Java, as it is the nickname for the late Abdurahman Wahid, who is popularly known as Gusdur. Although Taqiyudin is not East Javanese, he believes that this designation is still relevant. In addition, the @gustaqi name, for an Instagram account, sounds more populist and marketable, as it is easily understood by the public.

Taqiyudin graduated from Syarif Hidayatullah State Islamic University, Jakarta, and has been a board member of MUI in Bogor since 2017. In addition to lecturing at several universities in Bogor and Jakarta, Taqiyudin is also a media consultant for da'wa communities, a trainer, a public speaker, and a caretaker of Pondok Pesantren As-Saadah in Bogor. Like most Instagram accounts with da'wa contents, the @gustaqi account contains Islamic knowledge in various forms: quotations from the Quran or hadith, inspiring short videos, and announcements of his lectures. Taqiyudin expressed that his motivation to use Instagram was an effort to expand Islamic teachings, especially in reaching millennial groups. This is as expressed by Taqiyudin:

Today, people need messages that tend to be concise but meaningful. There are not many dalil (arguments from religious texts) that are philosophical, reflective, easy to understand, and acceptable to most people (Interview).

In order to be easily accessible and understood by most people, Taqiyudin explained that the messages of da'wa on Instagram must be practical, straightforward, informative, and easily understandable. In addition, since da'wa's audience on the internet comes from various groups, the messages must avoid themes such as politics, hatred, racism, intolerance, and harsh sentences. That is why, according to him, da'wa messages in the @gustaqi account are intended to make people enlightened and inspired by Islamic teachings. In addition, the use of social media is not only due to the popularity and ease of the media itself, but also to allow Muslims easy access to Islamic knowledge while carrying out daily activities. This is as stated by Taqiyudin:

It should be understood that today not everyone has the opportunity to be present at the islamic learning forum or majlis taklim physically, for various reasons and obstacles, but the posting of Islamic videos and contents through social media makes people continue to gain knowledge. Furthermore, after watching the video and other contents of this account, these people could decide to attend Islamic lectures in person (Interview).

The content of this account mostly addresses themes about the virtues of morality, motivation, self-confidence, Islamic lifestyle, as well as a brief guide for ritual worship. Regarding the short videos posted on @gustaqi, Taqiyudin confirmed that delivering da'wa messages in less than one minute was not easy, so he needed technical assistance from others to ensure that the content was technically proper. Interestingly, Taqiyudin still sees online-offline relations in religious practice as complementary. This is shown by his expectation that the @gustaqi account will not only provide Islamic knowledge but will also encourage users to engage in traditional Islamic learning. This implies that, as a religious figure who negotiates with the characteristics of social media, Taqiyudin believes that online and offline contexts can complement each other.

\subsection{Smartphone-Based Islamic Apps}

The popularity of smartphones in the daily lives of Indonesian Muslims has prompted software developers to take advantage of this gap in conveying religious information and knowledge, especially through applications (apps). On the Android platform alone, there are hundreds of Islamic applications under different categories, such as prayer times, qibla direction, a duas (prayers) collection, warits 
(inheritance), a hajj (pilgrimage) guide, and other general pieces of religious information, which are framed as da'wa.

One example of a da'wa app is the 'Aa Gym' app. This Islamic app is managed by KH Abdullah Gymnastiar and is popularly known as Aa Gym (Aa in the local language means older brothers). Gymnastiar has been a popular preacher in Indonesia and is the leader of Pondok Pesantren Daarut Tauhiid in Bandung, West Java. He is widely known as a creative preacher who uses cutting-edge technologies (Hoesterey 2009, 2015; Solahudin 2008). Long before the 'Aa Gym' app was launched, Gymnastiar had a project called Al-Quran Seluler in 2001; in 2009, he also launched an SMS-based Islamic lecturing service called SMS Tauhiid (Fakhruroji 2014, 2015a, 2015b). Gymnastiar is fully aware that the development of information and communication technology has changed the ways in which people engage with Islamic teachings. He considers these changes to represent an opportunity for religious lectures to utilize the internet, to ensure that such religious messages can still be accessed easily.

Originally, in an offline context, themes of Islamic lectures delivered by Gymnastiar used the jargon of 'manajemen qolbu' (management of heart)—namely, how to maintain the purity of heart found in many Islamic Sufism traditions. In addition to oral lectures, Gymnastiar also published dozens of Islamic books that were all written on similar themes. This modern style of Sufism also appears in the "Aa Gym" app, whose contents are mostly related to messages on improving one's self-quality through efforts to purify their heart. In addition, the 'Aa Gym' app also features short audio and video clips, as well as streaming radio and television. The 'Aa Gym' app is one example of the practice of convergent da'wa, namely the practice of da'wa by combining various channels in an all-in-one application (Fakhruroji 2018). The 'Aa Gym' app illustrates how smartphone-based Islamic apps represent Islamic learning practices on the internet.

The context of Islamic learning on the internet in Indonesia, as described above, shows a constructive relationship between the internet and religion. Some concerns about religious populism as a risk for Islamic learning on the internet have been ignored through the expansion of the authority of religious figures and institutions. Some of these examples show that the negotiation between religion and the internet can be maintained; religion can even expand its authority, so it will remain 'legitimate'. Therefore, religion in the offline context should not worry about the existence of Islamic learning practices on the internet as long as internet practices contextualize offline authority in the digital context. Through this contextualization, religion in a traditional-offline context can still maintain its position as the primary source of religious knowledge.

\section{Conclusions}

Although worries over religious populism have long been a concern of researchers, in digital religion studies, the relationship between the internet—as well as technology in general—and religion is essentially reciprocal and interconnected. This is partly because technology not only influences the world beyond our existence but also enters our world in its own way, thereby opening new possibilities for being and becoming through technology (Katz and Aakhus 2004). Online-offline reciprocal relationships are basically intended to describe the interconnections between the context of Islamic learning practices on the internet and traditional practices in offline contexts. Thus, online Islamic learning practices will never be separated from traditional religious frameworks, and the offline context will remain the main source for online religious practices.

Under this assumption, online-offline differences should no longer be a problem, since the internet has become a part of Muslims' daily lives. Islamic knowledge on the internet, as presented in this article, has demonstrated this reciprocal relationship. Cyberdakwah.com which collaborates with a pesantren to answer questions about Islam, UAS's Islamic lecture videos on the Tafaqquh Channel, the Instagram accounts of @gustaqi, and the "Aa Gym" app illustrate the negotiation efforts conducted by religious figures and institutions within the context of digital culture.

Therefore, Islamic learning practices on the internet should not be understood only as a form of religious populism that challenges religious authority but also as an opportunity to extend 
religious authority in a digital context. Some examples presented in this article have shown how traditional-offline religious authorities negotiate with the internet-online context in order to establish contextual relationships in contemporary Islamic societies.

Author Contributions: Conceptualization, M.F.; Formal analysis, M.F. and D.S.; Investigation, M.F.; Methodology, M.F. and D.S.; Writing—original draft, M.F.; Writing—review \& editing, M.F. and D.S.; All authors have read and agreed to the published version of the manuscript.

Funding: This research received no external funding.

Conflicts of Interest: The author declares no conflict of interest.

\section{References}

Abdel-Fadil, Mona. 2015. Counselling Muslim Selves on Islamic Websites: Walking a Tightrope Between Secular and Religious Counselling Ideals? Journal of Religion, Media and Digital Culture 4: 1-38. [CrossRef]

Abts, Koen, and Stefan Rummens. 2007. Populism versus democracy. Political Studies 55: 405-24. [CrossRef]

Ahyar, Muzayyin, and Alfitri Alfitri. 2019. Aksi Bela Islam: Islamic clicktivism and the new authority of religious propaganda in the millennial age in Indonesia. Indonesian Journal of Islam and Muslim Societies 9: 1-29. [CrossRef]

Arditi, Benjamin. 2003. Populism, or Politics at the Edges of Democracy. Contemporary Politics 9: 17-31. [CrossRef]

Barendregt, Bart. 2009. Mobile Religiosity in Indonesia: Mobilized Islam, Islamized Mobility and the Potential of Islamic Techno Nationalism. In Living the Information Society in Asia. Edited by I. Alampay. Singapore: Yusof Ishak Institute, pp. 73-92.

Brasher, Brenda E. 2001. Give Me that Online Religion. San Fransisco: Jossey-Bass Inc.

Bunt, Gary R. 2003. Islam in the Digital Age: E-Jihad, Online Fatwas, and Cyber Islamic Environments. London: Pluto Press.

Bunt, Gary R. 2010. Surfing the App Souq: Islamic Applications for Mobile Devices. CyberOrient 4. Available online: http://www.cyberorient.net/article.do?articleId=3817 (accessed on 12 August 2019).

Campbell, Heidi A. 2005a. Exploring Religious Community Online: We are One in the Network. New York: Peter Lang Publishing.

Campbell, Heidi A. 2005b. Making space for religion in Internet studies. Information Society 21: 309-15. [CrossRef]

Campbell, Heidi A. 2007. Who's got the power? Religious authority and the Internet. Journal of Computer-Mediated Communication 12: 1043-62. [CrossRef]

Campbell, Heidi A. 2012. Religion and the Internet: A microcosm for studying Internet trends and implications. New Media and Society 15: 680-94. [CrossRef]

Campbell, Heidi A. 2013. Digital Religion: Understanding Religious Practice in New Media Worlds. London and New York: Routledge.

Campbell, Heidi A., and Giulia Evolvi. 2019. Contextualizing current digital religion research on emerging technologies. Human Behavior and Emerging Technologies, 1-13. [CrossRef]

Campbell, Heidi A., and Mia Loveheim. 2011. Studying the online-offline connection in religion online. Information, Communication \& Society 14: 1083-96.

Campbell, Heidi A., Brian Altenhofen, Wendi Bellar, and Kyong J. Cho. 2014. There's a religious app for that! A framework for studying religious mobile applications. Mobile Media \& Communication 2. [CrossRef]

Castells, Manuel. 2009. The Rise of the Network Society, 2nd ed. Oxford: Wiley-Blackwell.

Chiluwa, Innocent. 2012. Online Religion in Nigeria: The Internet Church and Cyber Miracles. Journal of Asian and African Studies 47: 734-49. [CrossRef]

Cloete, Anita L. 2016. Mediated religion: Implications for religious authority. Verbum et Ecclesia 37: 1-16. [CrossRef]

Dawson, Lorne L., and Douglas E. Cowan. 2004. Religion Online: Finding Faith on the Internet. London and New York: Routledge.

della Porta, Donatella. 2014. Social Movements in Times of Austerity: Bringing Capitalism Back in. Cambridge: Polity Press.

Dream.co.id. n.d. Menteri Lukman: Jangan Belajar Islam dari Internet. Available online: https://www. dream.co.id/news/menteri-lukman-ingatkan-belajar-islam-jangan-dari-internet-160201n.html (accessed on 18 April 2018). 
Ernesto Laclau. 2005. On Populist Reason. London: Verso.

Fakhruroji, Moch. 2014. Agama dalam Pesan Pendek: Mediatisasi dan Komodifikasi Agama dalam SMS Tauhiid. Yogyakarta: Sekolah Pascasarjana Universitas Gadjah Mada.

Fakhruroji, Moch. 2015a. Mediatization of Religion in "Texting Culture": Self-Help Religion and the Shifting of Religious Authority. Indonesian Journal of Islam and Muslim Societies 5: 231-54. [CrossRef]

Fakhruroji, Moch. 2015b. SMS Tauhiid sebagai Tekno-religion: Perspektif Tekno-kultur atas Penyebaran Tausiah Agama melalui SMS. Sosioteknologi 14: 246-60. [CrossRef]

Fakhruroji, Moch. 2018. Digitalizing Islamic lectures: Islamic apps and religious engagement in contemporary Indonesia. Contemporary Islam 13: 201-15. [CrossRef]

Giorgi, Alberta. 2019. Mediatized Catholicism-Minority Voices and Religious Authority in the Digital Sphere. Religions 10: 463. [CrossRef]

Golan, Oren, and Nurit Stadler. 2016. Building the sacred community online: The dual use of the Internet by Chabad. Media, Culture and Society 38: 71-88. [CrossRef]

Helland, Christopher. 2004. Popular Religion and the World Wide Web: A Match Made in (Cyber) Heaven. In Religion Online. London: Routledge.

Helland, Christopher. 2005. Online Religion As Lived Religion. Methodological Issues In The Study Of Religious Participation On The Internet. Heidelberg Journal of Religions on the Internet 1: 16. [CrossRef]

Hjarvard, Stig. 2011a. The Mediatisation of Religion: Theorising religion, media and social change. Culture and Religion 12: 119-35. [CrossRef]

Hjarvard, Stig. 2011b. Three Forms of Mediatized Religion Changing the Public Face of Religion. Göteborg: Nordicom.

Hoesterey, James B. 2009. Sufis and Self-Help Gurus: Islamic Psychology, Religious Authority, and Muslim Subjectivity in Contemporary Indonesia. Madison: University of Wisconsin.

Hoesterey, James B. 2015. Rebranding Islam: Piety, Prosperity, and a Self-Help Guru. Stanford: Stanford University Press.

Hoover, Stewart M. 2006. Religion in the Media Age. New York: Routledge.

Husein, Fatimah, and Martin Slama. 2018. Online piety and its discontent: Revisiting Islamic anxieties on Indonesian social media. Indonesia and the Malay World 46: 80-93. [CrossRef]

Ibrahim, Saad Eddin. 1998. The Troubled Triangle: Populism, Islam and Civil Society in the Arab World. International Political Science Review 19: 353-85. [CrossRef]

id. techinasia.com. n.d. Jumlah Pengguna Facebook mobile indonesia tertinggi dunia. Available online: https: //id.techinasia.com/jumlah-pengguna-facebook-mobile-indonesia-tertinggi-dunia (accessed on 2 July 2019).

Jurriëns, Edwin, and Ross Tapsell. 2017. Digital Indonesia: Connectivity and Divergence. Singapore: Yosuf Ishak Institute.

Karaflogka, Anastasia. 2002. Religious discourse and cyberspace. Religion 32: 279-91. [CrossRef]

Katz, James E., and Mark Aakhus. 2004. Perpetual Contact: Mobile Communication, Private Talk, Public Performance. Cambridge: Cambridge University Press.

Lawrence, Bruce B. 2002. Allah On-Line: The Practice of Global Islam in the Information Age. In Practicing Religion in the Age of the Media. Edited by S. M. Hoover and L. S. Clark. New York: Columbia University Press. [CrossRef]

Lengauer, Dayana. 2018. Sharing Semangat Taqwa: Social media and digital Islamic socialities in Bandung. Indonesia and the Malay World 46: 5-23. [CrossRef]

Loveheim, Mia. 2008. Rethinking Cyberreligion? Nordicom Review 29: 205-17. [CrossRef]

Martin-Barbero, J. 1993. Communication, Culture and Hegemony: From Media to Mediations. London: SAGE Publications Ltd.

Millie, Julian. 2017. Hearing Allah's Call: Preaching and Performance in Indonesian Islam. New York: Cornell University Press.

Moffitt, Benjamin, and Simon Tormey. 2014. Rethinking Populism: Politics, mediatisation and political style. Political Studies 62: 381-97. [CrossRef]

Mussio, Louise A. 1996. The Origins and Nature of the Holiness Movement Church: A Study in Religious Populism. Journal of the Canadian Historical Association 7: 81-104. [CrossRef]

Nisa, Eva F. 2018. Creative and Lucrative Da'wa: The Visual Culture of Instagram amongst Female Muslim Youth in Indonesia. Asiascape: Digital Asia 5: 68-99. [CrossRef] 
O'Leary, Stephen D. 1996. Cyberspace as Sacred Space: Communication Religion on Computer Networks. Journal of the American Academy of Religion LXIV: 781-808.

Possamai, Adam, and Bryan S. Turner. 2014. Authority and liquid religion in cyber-space: The new territories of religious communication. International Social Science Journal 63: 197-206. [CrossRef]

Purbo, Onno W. 2017. Narrowing the Digital Divide. In Digital Indonesia: Connectivity and Divergence. Edited by Edwin Jurriëns and Ross Tapsell. Singapore: Yusof Ishak Institute, pp. 75-92.

Slama, Martin. 2010. The Agency of the Heart: Internet Chatting as Youth Culture in Indonesia. Social Anthropology/Anthropologie Sociale 18: 316-30. [CrossRef]

Slama, Martin. 2017. A subtle economy of time: Social media and the transformation of Indonesia's Islamic preacher economy: Social Media and Indonesia's Islamic Preacher Economy. Economic Anthropology 4: 94-106.

Solahudin, Dindin. 2008. The Workshop for Morality: The Islamic Creativity of Pesantren Daarut Tauhid in Bandung, Java. Canberra: ANU E Press.

Urbinati, Nadia. 1998. Democracy and Populism. Constellations 5: 110-24. [CrossRef]

WeAreSocial. n.d. Available online: http://www.wearesocial.com/sg (accessed on 12 August 2018).

Weng, Hew W. 2015. Dakwah 2.0: Digital Dakwah, Street Dakwah and Cyber-Urban Activism among Chinese Muslims in Malaysia and Indonesia'. In New Media Configurations and Socio-Cultural Dynamics in Asia and the Arab World. Edited by S. Nadja-Christina and C. Richter. Baden-Baden: Nomos Verlagsgesellschaft, pp. 198-221.

Weyland, Kurt. 2001. Clarifying a Contested Concept: Populism in the Study of Latin American Politics. Comparative Politics 34: 1-22. [CrossRef]

Zaleski, Jeffrey P. 1997. The Soul of Cyberspace: How New Technology Is Changing Our Lives. New York: Harper Collins.

(C) 2019 by the authors. Licensee MDPI, Basel, Switzerland. This article is an open access article distributed under the terms and conditions of the Creative Commons Attribution (CC BY) license (http://creativecommons.org/licenses/by/4.0/). 